\title{
Environmental Toxicant Clinician Knowledge Deficit: A Review of the Evidence
}

Sandra A Kreizenbeck and Travis K Svensson*

University of San Francisco, School of Nursing and Health Professions, Burlingame, California, USA

\begin{abstract}
With the increase in a wide array of medical, behavioral and psychiatric conditions and the belief that chemicals are playing a role in their rise, it is essential that clinicians understand risk factors of toxic chemicals so that they can educate their patients and thus hopefully prevent the occurrence of multiple health concerns. The failure to find any evidence-based reliable and valid tools to assess toxicant exposure and knowledge in the clinician and a patient, it was concluded that while medical science continues to advance on the epidemiology of autism, correlation of toxicant exposure in relation to autism and its treatment lack in the nursing science. There are many implications for practice in advancing the nursing science on toxicant knowledge, exposure, treatment and prevention. In terms of epidemiology, there is a need for more research on identifying the epidemiological contributing factors of autism spectrum disorder.
\end{abstract}

Keywords: Autism; Toxicants; Environmental factors; Advanced nursing knowledge

\section{Introduction}

The number of children affected with autism spectrum disorder today is astonishing. Between 2006-2008, the CDC identified that 1 in 68 children were affected by autism and 1 in 6 children were found to have a developmental delay [1]. To date, there is a growing controversy over whether the increase in prevalence of both is secondary to better diagnosis or environmental exposure. As a result, it is essential that clinicians understand environmental toxin exposure, so that in turn if they educate their patient about both its prevention and treatment, it will hopefully decrease risk factors that will in turn produce better outcomes [2].

Given increased exposure to the burning of fossil fuel and the emissions in the air from pesticides and other pollutant chemicals found in fragrances, pressure treated wood, vinyl, dry cleaning, plastics, mold dust, lead paint and toxicants such as flame retardants, PVC, BPA, phthalates, ozone, asbestos, radon, and formaldehyde, clinicians need to be well informed on how to educate their patients on how to reduce their exposure to minimize their risks.

The purpose of this review of the evidence paper is to find the following: a) clinician attitudes, beliefs and understanding on prevention and treatment of toxic chemical exposure b) reliable and valid tools to assess clinician's knowledge on preventing and treating toxic exposure and c) evidence-based teaching strategies for how to educate clinicians about preventing and treating toxic chemical exposure in patients and their children.

\section{PICOT Question}

In primary and secondary care providers treating potentially expectant or expectant parents that have another child on the autism spectrum, how does a CE workshop on preventing and minimizing toxicant exposure affect knowledge about toxicant exposure risk factors and prevention strategies within workshop time frame?

\section{Search strategy}

Data bases used to research this topic included the following:
PUBMED, CINAHL, Proquest, Evidence-Based Journals and Cochrane/DARE. Search terms included the following: environmental health, clinicians, attitude, belief, practice, competence and training," environmental health" and "primary care" or providers or clinicians or "nurse practitioners" or doctors or resident and knowledge or understand or aware or education and environmental risk factor tools and patient education and tool or instrument or assessment or measure or intervention and knowledge or aware or understand or educate. Inclusion criteria consisted of articles found within the past 15 years and primary care providers in a primary care setting. Articles were discarded if they failed to make mention of clinician understanding, practice or education centered on toxicant exposure. Search of the databases yielded a total finding of 27 articles, of which 24 were evaluated and 5 were used because they best answered the PICOT question and provided the strongest evidence.

\section{Description of Theoretical Framework}

\section{Knowles theory of adult learning theory}

The theoretical framework that guided this DNP project was Knowles' theory of adult learning. Knowles's theory is described below and in Appendix A. Knowles' adult learning theory is also known as andragogy theory, which of particular interest, as andragogy is another name for "adult learning." Malcolm Knowles developed the first five assumptions of Knowles' adult learning theory in 1980 and the last of the assumptions was added in 1984. Knowles' adult learning theory consists of six assumptions. The six assumptions are as follows: Need to know, Self-Concept, Experience, Readiness to learn, Orientation to learning and Motivation.

*Corresponding author: Travis K Svensson, Professor, University of San Francisco, SONHP, 25 Edwards Court \#102, Burlingame, California-94010, USA Tel: 6505043801; Fax: 6503481515; E-mail: tksvensson@aol.com

Received May 31, 2015; Accepted September 01, 2016; Published September 08,2016

Citation: Kreizenbeck SA, Svensson TK (2016) Environmental Toxicant Clinician Knowledge Deficit: A Review of the Evidence. Adv Practice Nurs 2:123. doi 10.4172/2573-0347.1000123

Copyright: @ 2016 Kreizenbeck SA. This is an open-access article distributed under the terms of the Creative Commons Attribution License, which permits unrestricted use, distribution, and reproduction in any medium, provided the original author and source are credited. 
Appendix A: Knowles' Assumptions of Adult Learners.

Knowles' adult learning theory (2005) consists of six assumptions. McEwen et al. presents the six assumptions are as follows:

1) Need to know-Adults need to know why they need to know something; 2) Self Concept-As people mature their self-concept moves from being one of being dependent toward one of being self-directed; 3) Experience-As people mature they accumulate a large amount of experience that can serve as a rich resource for learning 4) Readiness to learn-Real-life problems or situations create a readiness to learn in the adult.

5) Orientation to learning-As a person matures his or her time perspective changes from one of postponed application of knowledge to immediacy of application.

6) Motivation-Adults are primarily motivated by desire to solve immediate and practical problems. As a person matures, motivation to learn is stimulated by internal stimuli rather than external stimuli.

Knowles' adult theory was very helpful in identifying environmental toxicant clinician knowledge deficit in many ways, which in turn helped guide this Evidenced-Based Quality Improvement Project. First and foremost, under the first assumption of the theory, if a clinician is able to better understand the importance of the mental and physical health risk factors that can incur from exposure to environmental toxicant risk factors, then they will be more apt to embrace identifying what they lack in knowledge on this subject. In doing so, this will allow the clinician under Knowles' second assumption to be more driven to learn. Once drive is established, under Knowles' third assumption, a clinician will be able to apply their own life experience or that of their patient's life experiences to learning how to prevent and treat toxicant risk factors. Once application of life experiences are established, under Knowles' fourth assumption, the clinician will be more willing to learn. Under
Knowles' fifth assumption, once willingness to learn is established, it makes the clinician better able to apply learned knowledge to real life patient scenarios. Lastly, if all five assumptions are established, under Knowles' sixth assumption, the clinician will be better motivated to understand what they don't know about toxicant risk factor prevention and treatment and thus learn better [3-7].

Knowles' adult learning theory was used to establish how to assess for knowledge deficit and once done so helped provide a template on how to teach prevention and treatment of toxicant exposures. Knowles' adult learning theory helped identify clinician toxicant knowledge deficit variables by allowing the clinician to understand what that they lack in knowledge, so in doing so, can help them better learn. Although Knowles' adult learning theory didn't identify outcome measures, it is safe to say that by using this theory as a guide towards assessing for clinician toxicant knowledge deficit, it can guide the teacher towards being through, which in turn can help the teacher better identify outcome measures. Although Knowles' theory did not directly assist this author in evaluating outcome measures, one can include indirectly if identification of toxicant knowledge deficit in the clinician is identified and subsequently toxicant prevention and risk factors are taught, then patient mental and physical health outcomes will thus improve.

\section{Review of the Evidence}

\section{Identification of the problem}

The first step of this extensive literature review was to search the evidence to find published evidence-based research articles evaluating if there is a correlation between toxicant exposure and autism. Rossignol et al. [8] summarized in a succinct fashion that there was indeed a correlation between toxicant exposure and autism and that more study needed to be done on this subject. Six studies that were evaluated in Rossignol et al. systematic review on whether or not there was a correlation between autism and toxicant exposure centered around air

\begin{tabular}{|c|c|c|c|c|c|c|c|c|}
\hline Citation & $\begin{array}{l}\text { Conceptual } \\
\text { Framework }\end{array}$ & Design/ Method & Sampl/ Setting & $\begin{array}{c}\text { Variables Studied } \\
\text { and Their } \\
\text { Definition }\end{array}$ & Measurement & Data Analysis & Findings & $\begin{array}{l}\text { Appraisal: } \\
\text { Worth to } \\
\text { Practice }\end{array}$ \\
\hline $\begin{array}{l}\text { Devine, et } \\
\text { al. [4] }\end{array}$ & $\begin{array}{l}\text { Used a } \\
\text { Theoretical } \\
\text { Framework but } \\
\text { wasn't clear on } \\
\text { the title }\end{array}$ & $\begin{array}{l}\text { Pilot, Recruitment } \\
\text { of minority youth } \\
\text { aged } 14-18, \\
\text { Obtain surveys } \\
\text { pre and post } \\
\text { texting program }\end{array}$ & $\begin{array}{l}30 \text { males, } 29 \\
\text { females aged } \\
14-18 . \text { One third } \\
\text { Latino, two thirds } \\
\text { African American }\end{array}$ & $\begin{array}{l}\text { To study a cell } \\
\text { phone texting } \\
\text { system as an } \\
\text { adjunct to a teen } \\
\text { outreach program } \\
\text { to help diminish } \\
\text { "teen pregnancy } \\
\text { and drop out" }\end{array}$ & $\begin{array}{l}\text { Gave statistics but } \\
\text { was not clear how } \\
\text { the results were } \\
\text { measured }\end{array}$ & $\begin{array}{l}\text { "Analysis showed } \\
\text { a } 49 \% \text { response } \\
\text { rate to messages } \\
\text { that needed a reply } \\
\text { and a decrease } \\
\text { in compliance if } \\
\text { texting was done } \\
\text { over a long period } \\
\text { of time" }\end{array}$ & $\begin{array}{l}\text { "Attention to social } \\
\text { and behavioral } \\
\text { theory" may result } \\
\text { in a curriculum } \\
\text { that emphasizes } \\
\text { the teen outreach } \\
\text { program }\end{array}$ & $\begin{array}{l}\text { John Hopkins } \\
\text { University } \\
\text { Research } \\
\text { Evidence } \\
\text { Appraisal } \\
\text { Tool rating V, } \\
\text { Quality A }\end{array}$ \\
\hline $\begin{array}{l}\text { Harvey, et } \\
\text { al. [7] }\end{array}$ & None & $\begin{array}{l}\text { Case studies in } \\
5 \text { environmental } \\
\text { health } \\
\text { departments in } \\
\text { England, Scotland } \\
\text { and Northern } \\
\text { Ireland }\end{array}$ & $\begin{array}{l}5 \text { environmental } \\
\text { health } \\
\text { departments in } \\
\text { England, Scotland } \\
\text { and Northern } \\
\text { Ireland }\end{array}$ & $\begin{array}{l}5 \text { environmental } \\
\text { health } \\
\text { departments } \\
\text { in England, } \\
\text { Scotland and } \\
\text { Northern Ireland } \\
\text { effectiveness } \\
\text { of use of } \\
\text { environmental } \\
\text { health handouts }\end{array}$ & $\begin{array}{l}\text { This paper gave } \\
\text { statistics but was } \\
\text { not forthright how } \\
\text { the statistics were } \\
\text { evaluated }\end{array}$ & $\begin{array}{l}10 \text { people thought } \\
\text { that the text was } \\
\text { too little and the } \\
\text { pictures were } \\
\text { not condusive to } \\
\text { learning, Too much } \\
\text { to read }\end{array}$ & $\begin{array}{l}\text { To be conscious } \\
\text { of giving out } \\
\text { brochures for } \\
\text { education and } \\
\text { to ensure that } \\
\text { when done so } \\
\text { to follow up to } \\
\text { ensure optimal } \\
\text { understanding, } \\
\text { Handouts can } \\
\text { be helpful in } \\
\text { developing } \\
\text { understanding } \\
\text { on this subject } \\
\text { but more } \\
\text { research needs } \\
\text { to be done to } \\
\text { ensure adequate } \\
\text { understanding }\end{array}$ & $\begin{array}{l}\text { John Hopkins } \\
\text { University } \\
\text { Research } \\
\text { Evidence } \\
\text { Appraisal } \\
\text { Tool rating V, } \\
\text { Quality A }\end{array}$ \\
\hline
\end{tabular}




\begin{tabular}{|c|c|c|c|c|c|c|c|c|}
\hline $\begin{array}{l}\text { Massaquoi, et } \\
\text { al. [10] }\end{array}$ & None & $\begin{array}{l}\text { Systematic } \\
\text { Review } \\
\text { Five databases } \\
\text { were searched } \\
\text { using Google, } \\
\text { Yahoo and } \\
\text { Microsoft }\end{array}$ & $\begin{array}{l}\text { Primary } \\
\text { care providers }\end{array}$ & $\begin{array}{l}\text { "Review of } \\
\text { PCPS attitude, } \\
\text { belief, competency } \\
\text { and training on } \\
\text { toxicant exposure" }\end{array}$ & Not Disclosed & $\begin{array}{l}\text { Five databases } \\
\text { searched: } \\
\text { PUBMED, } \\
\text { MEDLINE, } \\
\text { SCOPUS, CINAHL } \\
\text { AND EMBASE }\end{array}$ & $\begin{array}{l}\text { Clinician's } \\
\text { knowledge of } \\
\text { how to assess for, } \\
\text { prevent and treat } \\
\text { toxicant exposure } \\
\text { were "inadequate" }\end{array}$ & $\begin{array}{l}\text { John } \\
\text { Hopkins } \\
\text { University } \\
\text { Research } \\
\text { Evidence } \\
\text { Appraisal } \\
\text { Tool rating V, } \\
\text { Quality A }\end{array}$ \\
\hline $\begin{array}{l}\text { Rosas, et } \\
\text { al. [9] }\end{array}$ & None & $\begin{array}{l}\text { Population- } \\
\text { Based case- } \\
\text { control study } \\
\text { use of a low } \\
\text { literacy touch } \\
\text { screen kiosk } \\
\text { device with audio, }\end{array}$ & $\begin{array}{l}\text { Latina prenatal } \\
\text { pregnant patients }\end{array}$ & $\begin{array}{l}\text { Understanding } \\
\text { on environmental } \\
\text { health education }\end{array}$ & $\begin{array}{l}\text { Mixed method } \\
\text { approach }\end{array}$ & $\begin{array}{l}90 \% \text { reported to } \\
\text { learn from the kiosk } \\
\text { and } 57 \% \text { preferred } \\
\text { to learn from kiosk } \\
\text { after using it }\end{array}$ & $\begin{array}{l}90 \% \text { of woman } \\
\text { in this study } \\
\text { reported to learn } \\
\text { about toxicant risk } \\
\text { factors from this } \\
\text { intervention }\end{array}$ & $\begin{array}{l}\text { John Hopkins } \\
\text { University } \\
\text { research } \\
\text { evidence } \\
\text { appraisal } \\
\text { rating tool V, } \\
\text { quality A }\end{array}$ \\
\hline $\begin{array}{l}\text { Rossignol, et } \\
\text { al. [8] }\end{array}$ & None & $\begin{array}{l}\text { Systematic review } \\
\text { of case control } \\
\text { and retrospective } \\
\text { studies }\end{array}$ & $\begin{array}{l}\text { Children with } \\
\text { autism }\end{array}$ & $\begin{array}{l}\text { Does the presence } \\
\text { of toxicants } \\
\text { predispose a child } \\
\text { to autism }\end{array}$ & Statistical Analysis & $\begin{array}{l}\text { Search of the data } \\
\text { bases through } \\
\text { Nov } 2013 \text { and } \\
2 \text { web based } \\
\text { environmentally } \\
\text { related genomic } \\
\text { data bases- The } \\
\text { National Institute } \\
\text { of Environmental } \\
\text { Health Genome } \\
\text { Project and Seattle } \\
\text { SNPS }\end{array}$ & $\begin{array}{l}\text { In addition } \\
\text { to genetic } \\
\text { predisposition, } \\
\text { toxicant exposure } \\
\text { increases the risk } \\
\text { of autism spectrum } \\
\text { disorder }\end{array}$ & $\begin{array}{l}\text { John hopkins } \\
\text { university } \\
\text { rating tool, } \\
\text { evidence V, } \\
\text { quality A }\end{array}$ \\
\hline
\end{tabular}

Table 1: Evidence Evaluation Table. Fineout-Overholt et al. [6].

pollution. It was interesting to note that these studies were conducted all over the world as far as Taiwan and they still presented with the same finding: that there was a higher prevalence of autism spectrum disorder in more polluted environments [9]. For a complete understanding of the critical appraisal of the evidence on this article Table 1. The John Hopkins University Research Evidence Appraisal Tool rating for this article was V, Quality A.

\section{Assessment of toxicant clinician knowledge}

The next step in the literature review was to determine the clinician knowledge of this subject. Since patient outcomes are better when clinician knowledge is proficient, it proved to be beneficial to evaluate a systematic review on mother and pediatric primary care provider's knowledge, thought process, feelings and education level around toxicant competency [10]. Massaquoi et al. [10] article is a systematic review designed to evaluate an advanced practice provider's understanding on identification and treatment in the event of contact with toxins. After review of the literature, eleven thousand two hundred and ninety one pieces of writing were identified, of which 43 articles qualified. Articles included in the search were from the years no earlier than 1999 and no later than 2015. Furthermore, the articles were not limited to a primary city or state, a certain clinician specialty or a certain type of toxin. Studies that were not evaluated included clinician's own impressions on toxicants or if the studies were conducted in the absence of a treating facility. In examining 43 articles, it was concluded that except for cigarette education, assessment and education of environmental toxin exposure were absent from routine patient care due to generalized understanding and past instruction on this subject and shortage on time that the clinician could spend with the patient. This systematic review recommended that more studies are needed to emphasize how a clinician teaches patient avoidance of toxicants and the necessary interventions to implement if exposed. The John Hopkins University Research Evidence Appraisal Tool rating was Level V, Quality A, Dearholt and Dang $[11,12]$.

\section{Tools}

After review of the literature that noted clinician knowledge deficit, this Author scoured the literature to find evidence-based tools that can be used to assess a clinician's understanding on this subject so that it can guide an environmental health curriculum accordingly on teaching knowledge deficit in the clinician. Unfortunately, this Author was unsuccessful in finding an evidence-based validated and reliable environmental toxicant knowledge assessment tool for both the clinician and the patient. There was; however, tools to include the Environmental Health Assessment Tool, Prenatal Assessment Tool and Planned Parenthood Green Choices Tool found, but none were validated and reliable. Schenk et al. created a Nurses' Environmental Awareness Tool (NAET) to help evaluate nurse's knowledge on toxicant exposure in the hospital, but in the context of decreasing autism risk factors, the tool could not be used. Having said this, there needs to be more study and research done to create an evidence-based validated and reliable formal tool to evaluate toxicant exposure knowledge, prevention and treatment for all expectant parents and existing parents to be used as a standard in practice.

\section{Education}

Once a tool has been dispersed to determine that that there is a knowledge deficit, education needs to occur. There are many ways to educate the clinician and their patient. As technology continues to advance, it is important to be mindful of using up to date educational tools to include direction in the use of evidence-based audio touch screen low literacy Kiosks, educational hand-outs and I phones that have application and texting features. People learn best by having information at their fingertips, whether it is to listen to an audio, watch a video, look at pictures or read informational hand-outs. It is important to be conscientious to the delivery of the education. If a patient or clinician are given an educational hand-outs with little explanation and follow up, then the education may be a moot point.

Devine et al. [4] conducted a pilot study on a minority teen population between 14-18 years of age to study a cell phone texting system as an adjunct to a teen outreach program to help diminish pregnancy and not graduating from high school. The results concluded if social and behaviour aspects were taken into consideration when 
implementing the program, that texting might enhance the curriculum. The John Hopkins University Research Evidence Appraisal Tool rating for this article was V, Quality A. When teaching clinicians and their patients about the harmful effects of toxicants, the same type of texting intervention may contribute to better understanding that can in turn, hopefully can make for better optimal health conditions in the presence of toxicants.

Harvey et al. [7] through a series of 5 case studies conducted in England, Scotland and Northern Ireland in Environmental health departments evaluated if the use of heath hand-outs were effective in patient understanding environmental risk factors better. The conclusion of the study noted that the delivery of the hand-outs and the follow up after the hand-outs was given was important when establishing understanding on environmental risk factors. Some of the participants in the study noted that a lengthy hand-outs, with small font and nonrelevant pictures took away from learning optimally. The conclusion of the study noted that health brochures can prove to be an effective teaching modality but follow up and attention to detail on the contents of the hand-outs to include font size, pictures and text length need to be taken into consideration when establishing toxicant understanding. The John Hopkins University Research Evidence Appraisal Tool rating for this article was V, Quality A. In the end, the study recommended that more research needs to be done on how to ensure that educational hand-outs enhance knowledge. In enhancing clinician and patient toxicant risk factor understanding, the educational technique of using a hand-outs in this study could prove to be beneficial when establishing environmental health knowledge.

Rosas et al. [9] conducted a population-based case-control study among Latina pregnant woman in the use of a low literacy touch screen kiosk device with audio, in an effort to evaluate if through its use, there was a better understanding of toxicant exposure. The conclusion of the study noted that $90 \%$ of woman in the study stated that they learned more about toxicant risk factors from this interventional approach and that $57 \%$ of the participants chose this form of educational teaching after being exposed to this type of teaching. The John Hopkins University Research Evidence Appraisal Tool rating for this article was V, Quality A. The use of a kiosk or IPAD in teaching toxicant risk factors could prove to be beneficial.

\section{Summary and Conclusions}

In summary, there were five research articles reviewed in this paper. When evaluated with the John Hopkins Research Evidence Appraisal Tool, they were all deemed to be excellent in "quality and strength" and support the lack of knowledge in advanced practice clinicians on how to assess for environmental risk factors and how to explain appropriate and realistic interventions if a patient comes in contact with toxic chemicals (Table 2).

This paper identified the current health care problem of increase in the prevalence of autism spectrum disorder. Once the clinical significance of autism was identified, a correlation between toxicant exposure and autism was identified with the presentation of Rossignol et al. [8] systematic review findings. After a positive link was identified between toxicant exposure and autism, clinician toxicant knowledge was assessed. In examining Massaquoi et al. systematic review, it was determined that there is a knowledge deficit in clinicians on defining prevention of toxicant exposures, how to assess for their potential toxic effects and what to do in terms of intervention if a patient should be exposed to toxicants. Once a trend in clinician toxicant knowledge deficit was identified, a PICOT question was defined. From there, the method used to find supporting literature was articulated and a theoretical framework was identified to guide the project. Next, based on failure to find any evidence-based reliable and valid tools to assess toxicant exposure and knowledge in the clinician and a patient, it was concluded that while medical science continues to advance on the epidemiology of autism, correlation of toxicant exposure in relation to autism and its treatment lack in the nursing science. After critical review of Devine et al. [4], Harvey et al. and Rosas et al., it was concluded that while education modalities in the way of use of electronic devices such as Kiosks, I Pads, applications on the I phone and informational hand outs proved to be helpful, more study needs to be done on the subject. In addition, literacy, age, culture and educational background should be taken into consideration when studying the effectiveness of toxicant teaching modalities. Lastly, the implications for practice on this subject are stated below.

\section{Implications for Practice}

With the increase in a wide array of medical, behavioural and psychiatric conditions and the belief that chemicals are playing a role in their rise, it is essential that clinicians understand risk factors

\begin{tabular}{|l|l|l|l|}
\hline Studies & \multicolumn{1}{|c|}{ Design } & \multicolumn{1}{|c|}{ Sample } & \\
\hline Devine, et al. [4] & Pilot study & $\begin{array}{l}\text { Male 58 } \\
\text { Female 38 } \\
\text { African-American 23 } \\
\text { Hispanic/Latino } 66 \\
14-15 \text { yrs-65 } \\
16-18 \text { yrs-31 }\end{array}$ & $\begin{array}{l}\text { "Attention to social and behavioral theory may result in a curriculum that emphasizes } \\
\text { the teen outreach program" }\end{array}$ \\
\hline Harvey, et al. [7] & Case study & $\begin{array}{l}5 \text { environmental health } \\
\text { departments in England, } \\
\text { Scotland and Northern Ireland }\end{array}$ & $\begin{array}{l}\text { To be conscious of giving out brochures for education and to ensure that when } \\
\text { done so to follow-up to ensure optimal understanding, Handouts can be helpful in } \\
\text { developing understanding on the subject, but more research is needed on how to } \\
\text { effectively institute this teaching strategy }\end{array}$ \\
\hline Massaquoi, et al. [10] & Systematic review & Primary care providers & $\begin{array}{l}\text { Clinician's knowledge of how to assess for, prevent and treat toxicant exposure was } \\
\text { "inadequate" }\end{array}$ \\
\hline Rosas, et al. [9] & $\begin{array}{l}\text { Population-based case- } \\
\text { control study }\end{array}$ & $\begin{array}{l}\text { Latina prenatal pregnant } \\
\text { patients }\end{array}$ & $\begin{array}{l}\text { 90\% of woman in this study "reported that they learned more about environmental } \\
\text { health from this approach" }\end{array}$ \\
\hline Rossignol, et al. [8] & $\begin{array}{l}\text { Systematic review } \\
\text { of case control and } \\
\text { retrospective studies }\end{array}$ & Children with autism & $\begin{array}{l}\text { In addition to genetic predisposition, toxicant exposure increases the risk of autism } \\
\text { spectrum disorder }\end{array}$ \\
\hline
\end{tabular}

Table 2: Evidence Synthesis. Fineout-Overholt et al. [6] 
of toxic chemicals so that they can educate their patients and thus hopefully prevent the occurrence of multiple health concerns. There are many implications for practice in advancing the nursing science on toxicant knowledge, exposure, treatment and prevention. In terms of epidemiology, there is a need for more research on identifying the epidemiological contributing factors of autism spectrum disorder. In PHD prepared nurses, there is a need for development of evidencebased valid and reliable environmental toxicant assessment tools. In terms of nursing practice, there is a need for DNP clinicians to apply evidenced-based change in practice interventions when identifying and addressing toxicant knowledge deficit in primary care providers and their patients. Having said this, there needs to be more research on not only how to define the effects of toxicant risk exposure to patients but how to teach safer alternative prevention strategies and practices through the use of I phone applications, I Pads, educational workshops and hand-outs and social media such as Face book and forums. In doing so, it is essential that more research be done on translating prevention of toxicant risk exposures across cultures and that education, literacy and socioeconomic factors be taken into account as well. In terms of nursing education, there needs to be a need for research in developing reliable and validated tools in teaching environmental health curriculum in medical and nursing schools. As a practicing clinician, there needs to be understanding of how toxicants affect patients down to the cellular level and how to assess, identify and treat accordingly when toxicants play a role in mitochondrial dysfunction, immune deficiency, autoimmunity, depression, anxiety, ADHD, developmental delay, seizures and dementia. In terms of administration implications for practice on this subject, environmental toxicant risk exposure policies need to be created and supported. It is important to understand that there are many moving parts when addressing this issue, but hopefully when clinician and patient toxicant knowledge are addressed, it will enable better understanding, that in turn may reduce patient toxic exposure and thus contribute to better outcomes in the long run.

\section{References}

1. Knowles M, Holton EF, Swanson RA (2005) The adult learner: The definitive classic in Environmental Toxicant Clinician Knowledge Deficit adult education and hormone resource development (6th edn.) Burlington, MA: Elsevier Reprinted in McEwen M, Willis E (2011) Theoretical basis for nursing (3rd ed.). Philadelphia, PA: Lippincott Williams \& Wilkins 364-365.

2. Balbus JM, Harvey CE, McCurdy LE (2006) Educational needs assessment for pediatric health care providers on pesticide toxicity. J Agromedicine 11: 7-38.

3. (2015) Center for Disease Control and Prevention. Autism spectrum disorder: Data \& statistics.

4. Devine S, Bull S, Dreisbach S, Shlay J (2013) Enhancing a teen pregnancy prevention with text messaging: Engaging minority youth to develop top plus text. J Adolesc Health 54: 578-583.

5. Schenk E, Butterfield P, Doshea J, Barbosa-Leiker C, Corbett C (2015) Creating the Nurses' environmental awareness tool. Workplace Health Saf 63: 381-391.

6. Fineout-Overhault E, Melnyk B (2015) Evidence-based Practice in nursing \& healthcare: A guide to best practice (3rd ed.). China: Lippincott Williams \& Wilkins

7. Harvey H, Fleming $P$ (2003) The readability and audience acceptance of printed health promotion materials used by environmental health departments. J Environ Health 65: 22-28.

8. Rossignol DA, Genius S, Frye R (2014) Environmental toxicants and autism spectrum disorders: A systematic review. Translational Psychiatry 4.

9. Rosas LG, Trujillo C, Camacho J, Madrigal D, Bradman A, et al. (2014) Acceptability of health information technology aimed at environmental health education in a prenatal clinic. Patient Educ Couns 97: 244-247.

10. Massaquoi LD, Edwards N (2015) A scoping review of maternal and child health clinicians attitudes, beliefs, practice, training and perceived self-competence in environmental health. Int J Environ Res Public Health 12: 15769-15781.

11. Steingraber S (2011) Raising Elijah: Protecting our children in an age of environmental crisis. Boston, MA: Da Capo Press.

12. Dearholt S, Dang D (2012) John Hopkins nursing evidence-based practice: Model and guidelines, (2nd edn.), Indianapolis, IND: Sigma Theta Tau. 